\title{
RESEARCH PAPER \\ Heterosis for yield contributing head traits in cabbage (Brassica oleracea var. capitata)
}

\author{
Beyhan Kibar', Onur Karaağaç², and Hayati $\mathrm{Kar}^{2}$ \\ 'Department of Horticulture, Faculty of Agriculture and Natural Sciences, Abant Izzet Baysal University, \\ Bolu, Turkey. \\ ${ }^{2}$ Black Sea Agricultural Research Institute, Department of Horticulture, Tekkeköy, Samsun, Turkey.
}

\begin{abstract}
B. Kibar, O. Karaağaç, and H. Kar. 2015. Heterosis for yield contributing head traits in cabbage (Brassica oleracea var. capitata). Cien. Inv. Agr. 42(2):205-216. The present investigation was carried out to study the direction and magnitude of heterosis in twenty-four hybrids for yield contributing head traits in cabbage (Brassica oleracea var. capitata L.). A field experiment was conducted during the cabbage growing season of 2011-2012 at the Black Sea Agricultural Research Institute, Samsun, Turkey. Hybrids and parents were evaluated in a randomized block design with three replications. Measurements were performed for head weight, head diameter and head length to estimate mid parent and better parent heterosis in each hybrid. The direction and magnitude of mid parent and better parent heterosis among hybrids for all the head traits was found to be highly variable. The maximum and significant heterosis in favorable directions both over mid parent and better parent for head weight (73.6 and 62.3\%, respectively), head diameter (39.6 and 39.1\%, respectively) and head length (25.3 and 21.6\%, respectively) was observed in the hybrid P8 $\times$ P14. In this study, the hybrids $\mathrm{P} 8 \times \mathrm{P} 14, \mathrm{P} 3 \times$ $\mathrm{P} 13, \mathrm{P} 3 \times \mathrm{P} 14$ and $\mathrm{P} 8 \times \mathrm{P} 13$ were found to be promising hybrid combinations with regard to their per se performance for head traits and the magnitude of heterosis. These hybrids can be selected for commercial exploitation of hybrid vigor. Thus, the information generated from this study might be vital and useful for breeders to develop hybrid varieties with better head traits and high yield through heterosis breeding.
\end{abstract}

Key words: Cabbage, hybrid vigor, breeding, head traits, yield, yield components.

\section{Introduction}

Cabbage (Brassica oleracea var. capitata L.), a member of Brassicaceae family, is an economically and nutritionally important vegetable crop that is grown and consumed widely around the globe (Chiang et al., 1993). Cabbage is gaining

Received June 26, 2014. Accepted May 4, 2015. Corresponding author: beyhan.kibar@ibu.edu.tr popularity worldwide because it is inexpensive, has wider adaptability, and is available year-round (Singh et al., 2010a). It is cultivated for its heads, which are consumed fresh in salads and in different culinary dishes and also preserved by pickling, dehydration or freezing (Posta and Berar, 2006). In addition, it is an important source of dietary nutrients and antioxidants (Kopsell et al., 2004; Hounsome et al., 2009; Singh et al., 2009a). 
Cabbage is also an integral part of Turkish cuisine owing to its excellent taste, rich chemical composition, availability at local markets and low cost. In Turkey, cabbage is grown in an area of 14685 ha with a production of 496864 tons and productivity of 33.8 ton ha $^{-1}$ (TUIK, 2014). Approximately $20 \%$ of the total cabbage produced is derived from Samsun province in the Black Sea Region. Although domestic cultivars are available in Turkey, $F_{1}$ hybrids are used for intensive cabbage production owing to the presence of heterosis (Kar et al., 2008). Heterosis, or hybrid vigor, refers to the superiority in performance of hybrid individuals compared with their parents (Shull, 1952). Today, heterosis is utilized as the most successful approach to increase the productivity of plants and hybrid breeding based on the heterosis effect, it is intensively used in cross-pollinated vegetable crops such as cabbage. High-yielding hybrids of cabbage can be developed successfully using heterosis breeding. Hybrid varieties have several advantages such as high yield, earliness, improved quality, uniformity, vigorous development and also resistance to diseases and pests. Hybrid varieties account for a significant proportion of cabbage production in Turkey; however, all hybrids are foreign and are very expensive. Information on the magnitude of heterosis is an important prerequisite for developing a good economically viable hybrid cabbage variety. Therefore, there is a great need to accelerate studies on heterosis with the aim of developing high-yielding hybrid varieties of cabbage in Turkey.

It is important to understand the degree and direction of hybrid vigor for its commercial exploitation. The magnitude of heterosis serves to guide the choice of desirable parents for developing superior $F_{1}$ hybrids. In addition to this, heterotic studies provide useful information for identifying true heterotic cross combinations, combining the abilities of the parents and their usefulness in hybridization programs (Singh et al., 2004). Different rates of heterosis have been reported in cabbage for quality traits and yield, as well as its various components, by various researchers (Pandey et al., 2004; Prakash and Verma, 2004; Pathak et al., 2007; Singh, 2007; Singh et al., 2009a,b). The results obtained in different studies on heterosis may vary according to environmental conditions, experimental materials and the properties of the experiments.

It was considered that head traits, such as head weight, head diameter and head length, play very important roles in cabbage yield, as these traits had highly significant and positive correlations with yield (Posta and Berar, 2006; Antonova, 2009; Singh et al., 2010b). Thus far, no studies have been performed describing heterosis for head traits associated with cabbage yield in Turkey. Thus, the present study was conducted to estimate the magnitude and the direction of heterosis over mid parent and better parent for yield contributing head traits in twenty-four hybrids and to identify promising parents and hybrids with better head traits for increasing cabbage productivity.

\section{Materials and methods}

The present investigation was carried out at the Black Sea Agricultural Research Institute, Samsun, Turkey during the cabbage growing period of 2011-2012. The experimental area is geographically situated at $41^{\circ} 13^{\prime} \mathrm{NL}$ and $39^{\circ} 29^{\prime}$ EL at an altitude of $6 \mathrm{~m}$ above mean sea level (masl). It has a mild and humid climate with an average annual rainfall of $721.4 \mathrm{~mm}$, annual relative humidity of $73.5 \%$, and mean annual air temperature of $14.4^{\circ} \mathrm{C}$ (TUMAS, 2013). The soil of the experimental area is clay-loam with a $\mathrm{pH}$ value of 6.9 , organic matter content of $1.36 \%$, and lime ratio of $7.24 \%$.

The experimental materials consisted of 14 diverse inbred lines that were used as parents and $24 \mathrm{~F}_{1}$ hybrids. The parental lines were improved at the Black Sea Agricultural Research Institute after inbreeding during 10 generations and chosen for the present study after preliminary evaluation of different traits. A detailed description of the 
parental lines used in the study is presented in Table 1. Twelve female parents (P1, P2, P3, P4, P5, P6, P7, P8, P9, P10, P11 and P12) were crossed with two male parents (P13 and P14) during the flowering period (April to May, 2011), and 24 cross combinations were obtained. Crosses were made manually using the standard procedure of hand emasculation and pollination. The seeds of $F_{1}$ hybrids were harvested 30-35 days after pollination and kept in cold storage.

The seeds of 38 cabbage materials were sown in multi-pot plastic trays on 18 July 2011, and seedlings were grown in a greenhouse according to standard procedures. The experiment was laid out in a randomized block design (RBD) with three replications. Each experimental plot consisted of two rows that were $7 \mathrm{~m}$ long with a row-to-row distance of $1 \mathrm{~m}$ and plant-to-plant distance of $0.7 \mathrm{~m}$. Thirty-five-day-old seedlings of $24 \mathrm{~F}_{1}$ hybrids along with 14 parents were transplanted in plots at the 4-5 true leaf stage. There were 20 plants for each hybrid and parent in each replication. The recommended agronomic practices and plant protection measures were followed uniformly to all the hybrids and parents for the duration of the experiment. At maturity, ten competitive plants were selected randomly from each of the $F_{1}$ hybrids and parents in each plot for observations. Data were recorded for head weight $(\mathrm{kg})$, head diameter $(\mathrm{cm})$ and head length $(\mathrm{cm})$, and the means were computed to estimate heterosis.

The data were subjected to statistical analysis using SPSS 10.0 and the SAS package (SAS Institute Inc., Version 9.0., Cary, NC, 2004).

The magnitude of heterosis was expressed as a percentage increase or decrease in the $\mathrm{F}_{1}$ hybrid over its mid parent (MP) and better parent (BP). Mid parent heterosis (relative heterosis) and better parent heterosis (heterobeltiosis) for all traits in each hybrid were calculated as suggested by Fonseca and Patterson (1968) using the following formulae.

Table 1. Description of the parental lines used in the study.

\begin{tabular}{|c|c|c|c|c|c|c|c|c|c|c|}
\hline $\begin{array}{l}\text { Parental } \\
\text { lines }\end{array}$ & Origin & $\begin{array}{l}\text { Plant } \\
\text { height } \\
(\mathrm{cm})\end{array}$ & $\begin{array}{c}\text { Plant } \\
\text { diameter } \\
(\mathrm{cm})\end{array}$ & $\begin{array}{l}\text { Days to } \\
\text { maturity }\end{array}$ & $\begin{array}{l}\text { Shape of head in } \\
\text { longitudinal section }\end{array}$ & $\begin{array}{c}\text { Density of } \\
\text { head }\end{array}$ & $\begin{array}{l}\text { Length of } \\
\text { interior } \\
\text { stem } \\
(\mathrm{cm})\end{array}$ & $\begin{array}{l}\text { Diameter of } \\
\text { interior stem } \\
(\mathrm{cm})\end{array}$ & $\begin{array}{l}\text { Opening } \\
\text { status } \\
\text { of leaves }\end{array}$ & $\begin{array}{c}\text { Internal } \\
\text { color of } \\
\text { head }\end{array}$ \\
\hline P1 & Samsun/Turkey & 32.0 & 63.0 & 134 & Transverse elliptic & Very dense & 8.5 & 3.0 & $\mathrm{Bad}$ & Whitish \\
\hline $\mathrm{P} 2$ & Sakarya/Turkey & 44.5 & 94.5 & 93 & Transverse elliptic & Medium & 9.0 & 4.0 & Good & Cream \\
\hline P3 & Samsun/Turkey & 44.0 & 86.5 & 100 & Transverse elliptic & Medium & 9.2 & 3.2 & Medium & Cream \\
\hline P4 & Tokat / Turkey & 66.0 & 111.0 & 101 & Transverse elliptic & Medium & 12.0 & 3.5 & Good & Cream \\
\hline P5 & USDA/USA & 41.0 & 72.0 & 91 & Circular & Dense & 8.0 & 3.7 & $\mathrm{Bad}$ & Yellowish \\
\hline P6 & USDA/USA & 36.0 & 49.0 & 133 & Circular & Loose & 10.5 & 3.0 & Good & Yellowish \\
\hline P7 & USDA/USA & 49.0 & 98.0 & 94 & $\begin{array}{c}\text { Transverse } \\
\text { narrow elliptic }\end{array}$ & Loose & 11.5 & 4.0 & Good & Cream \\
\hline P8 & USDA/USA & 39.5 & 88.5 & 92 & Transverse elliptic & Loose & 9.0 & 3.0 & Good & Whitish \\
\hline P9 & Bursa/Turkey & 57.5 & 106.0 & 124 & $\begin{array}{c}\text { Transverse } \\
\text { narrow elliptic }\end{array}$ & Medium & 9.5 & 3.2 & Good & Whitish \\
\hline P10 & Tokat/Turkey & 53.5 & 96.5 & 99 & Transverse elliptic & Medium & 9.0 & 4.0 & Medium & Cream \\
\hline P11 & Samsun/Turkey & 60.0 & 116.0 & 131 & $\begin{array}{c}\text { Transverse } \\
\text { narrow elliptic }\end{array}$ & Medium & 8.0 & 4.0 & Good & Yellowish \\
\hline $\mathrm{P} 12$ & Balıkesir/Turkey & 50.5 & 114.0 & 95 & $\begin{array}{c}\text { Transverse } \\
\text { narrow elliptic }\end{array}$ & Medium & 10.0 & 4.0 & Medium & Cream \\
\hline P13 & Samsun/Turkey & 42.5 & 84.5 & 102 & Circular & Medium & 10.5 & 3.5 & Medium & Cream \\
\hline P14 & USDA/USA & 40.0 & 85.0 & 123 & $\begin{array}{c}\text { Transverse } \\
\text { narrow elliptic }\end{array}$ & Medium & 9.0 & 2.5 & Good & Whitish \\
\hline
\end{tabular}


Mid parent heterosis $(\%)=\frac{(F 1-M P)}{M P} \times 100$

Better parent heterosis $(\%)=\frac{(F 1-B P)}{B P} \times 100$

where $F_{1}=$ mean value of the $F_{1}$ hybrid, $\mathrm{MP}=$ mean value of the two parents $\frac{(P 1+P 2)}{2}$, and $\mathrm{BP}=$ mean value of the better parent.

The statistical significance of heterosis was determined by t-test (Wynne et al., 1970).

\section{Results and discussion}

\section{Analysis of variance}

Analysis of variance for head traits is presented in Table 2, revealing significant differences $(\mathrm{P} \leq 0.01)$ among the genotypes with respect to head weight, head diameter and head length. This indicates the existence of sufficient genetic variability among hybrids and their parents, which is a prerequisite for improving traits through breeding. Melaku (1993) noted the importance of genetic diversity for the expression of heterosis. The differences among parents and crosses for all the traits were also highly significant $(\mathrm{P} \leq 0.01)$. These results are in agreement with the findings of Pathak et al. (2007) and Singh et al. (2009a), who observed significant differences in mean squares among parents and hybrids for various traits in cabbage. The mean squares of parents vs. crosses for all the traits investigated were significantly different $(\mathrm{P} \leq 0.01)$. In addition, the variance among lines was found to be highly significant $(\mathrm{P} \leq 0.01)$ for all the traits. Similarly, testers showed highly significant differences $(\mathrm{P} \leq 0.01)$ for all head traits studied except for head diameter. Additionally, as shown in Table 2 , the line $\mathrm{x}$ tester interaction was significant $(\mathrm{P} \leq 0.01)$ for all the traits. Our findings were similar to the results of Singh et al. (2009c) and Singh et al. (2011) for cabbage.
Mean performances of the parents and their crosses

The mean performances of 14 parents and 24 $\mathrm{F}_{1}$ hybrids regarding head traits are provided in Table 3. Head weight is the most important component affecting yield in cabbage; thus, a large head weight is of prime importance when breeding high-yield varieties. The mean values of head weight among the parents ranged from 1.00 to $3.70 \mathrm{~kg}$, whereas the mean data for this trait in $F_{1}$ hybrids ranged from 2.00 to $4.15 \mathrm{~kg}$. In all the parents examined, the maximum head weight was observed in parent $\mathrm{P} 4$, while the minimum head weight was noted in parent P6. The highest head weight among the hybrids was found in the hybrid P $3 \times$ P13 followed by the hybrids $\mathrm{P} 2 \times$ P13 and P8 $\times$ P14. However, the cross P10 $\times$ P13 was identified as having the lowest mean value for head weight.

Head diameter directly influences cabbage yield and is an important parameter in cabbage breeding. It is apparent from Table 3 that the mean head diameters of parents and $\mathrm{F}_{1}$ hybrids varied from 18.8 (P5) to $26.7 \mathrm{~cm}(\mathrm{P} 11)$ and $17.3(\mathrm{P} 11 \times \mathrm{P} 14)$ to $30.8 \mathrm{~cm}(\mathrm{P} 8 \times \mathrm{P} 14)$, respectively. The parents P11, P7 and P9 possessed high mean head diameter values, and the cross combinations $\mathrm{P} 8 \times \mathrm{P} 14, \mathrm{P} 8$ $\times \mathrm{P} 13$ and $\mathrm{P} 3 \times \mathrm{P} 13$ showed better performance $(>28.0 \mathrm{~cm})$ than the other hybrids for this trait.

Head length is also a major yield contributing character in cabbage. The parental head length means indicated that parents $\mathrm{P} 4$ and $\mathrm{P} 10$ had a maximum head length of $20.0 \mathrm{~cm}$, whereas parents P1 and P5 had the lowest head length of $15.5 \mathrm{~cm}$. Among the $24 \mathrm{~F}_{1}$ hybrids, the hybrid P11 $\times$ P13 displayed the highest value of head length (23.2 $\mathrm{cm}$ ), closely followed by hybrid P12 $\times \mathrm{P} 13$, with a mean value of $23 \mathrm{~cm}$. Conversely, the minimum head length was recorded in the cross P6 $\times$ P14 $(13.5 \mathrm{~cm})$. 
Table 2. Analysis of variance for head traits in cabbage.

\begin{tabular}{lcccc}
\hline & & \multicolumn{3}{c}{ Mean squares } \\
\cline { 3 - 5 } $\begin{array}{l}\text { Source of } \\
\text { variation }\end{array}$ & $\begin{array}{c}\text { Degrees of } \\
\text { freedom }\end{array}$ & $\begin{array}{c}\text { Head weight } \\
(\mathrm{kg})\end{array}$ & $\begin{array}{c}\text { Head diameter } \\
(\mathrm{cm})\end{array}$ & $\begin{array}{c}\text { Head length } \\
(\mathrm{cm})\end{array}$ \\
\hline Repetitions & 2 & $0.007 \mathrm{NS}$ & $2.970^{*}$ & $4.717^{* *}$ \\
Genotypes & 37 & $1.384^{* *}$ & $26.644^{* *}$ & $15.217^{* *}$ \\
Parents & 13 & $1.867^{* *}$ & $23.305^{* *}$ & $7.475^{* *}$ \\
Crosses & 23 & $1.150^{* *}$ & $27.714^{* *}$ & $18.527^{* *}$ \\
Parents vs. Crosses & 1 & $0.485^{* *}$ & $45.434^{* *}$ & $39.819^{* *}$ \\
Lines & 11 & $2.063^{* *}$ & $27.171^{* *}$ & $7.000^{* *}$ \\
Testers & 1 & $1.500^{* *}$ & $3.375 \mathrm{NS}$ & $20.167^{* *}$ \\
Line x Tester & 11 & $0.206^{* *}$ & $30.469^{* *}$ & $29.904^{* *}$ \\
Error & 74 & 0.011 & 0.906 & 0.800 \\
Total & 113 & & & \\
CV $(\%)$ & & 3.80 & 3.98 & 4.80 \\
Mean & & 2.69 & 23.89 & 18.63 \\
\hline
\end{tabular}

$* \mathrm{P} \leq 0.05, * * \mathrm{P} \leq 0.01, \mathrm{NS}:$ Non-significant.

From the mean performance of the genotypes, it is evident that, in general, hybrids exhibited greater variation compared to their parents with respect to head weight, head diameter and head length, and the mean values of hybrids were desirably higher than those of the parents for head traits. The higher mean value and range of hybrids in comparison with parents indicate the presence of positive heterosis in general. The prime criterion used for the evaluation of hybrids was based on per se performance of different traits. The hybrids $\mathrm{P} 3 \times \mathrm{P} 13, \mathrm{P} 8 \times \mathrm{P} 14$ and $\mathrm{P} 8 \times \mathrm{P} 13$ showed the highest per se performance with regard to the three traits studied.

The values of head weight, head diameter and head length of the parents and hybrids determined in this study were higher than those of Singh et al. (2009a). These differences may be attributed to diversity in experimental materials or other environmental factors.

\section{Heterosis}

In the present study, heterosis values estimated over mid parent (MP) and better parent (BP) for the head traits of hybrids are presented in Table
4. The magnitude and the direction of heterosis in hybrids showed great differences with respect to cross combinations and the studied traits. The number of crosses displaying significantly positive and negative heterosis, the range of heterosis and the best crosses for head traits are depicted in Table 5.

Head weight is considered to be associated directly with yield; therefore, positive heterosis for this trait is desirable. The heterosis values over mid parent for head weight among different $F_{1}$ hybrids ranged from $-34.4(\mathrm{P} 10 \times \mathrm{P} 13)$ to $73.6 \%$ $(\mathrm{P} 8 \times \mathrm{P} 14)$. In general, mid parent heterosis values were significant in most of the crosses for head weight. Although sixteen crosses exhibited positive heterosis over mid parent, heterosis at a significant level was observed in eleven crosses. Among the twenty-four cross combinations, five crosses had positive but non-significant mid parent heterosis for this trait. Eight cross combinations showed significantly negative heterosis over mid parent. The highest significant mid parent heterosis value was obtained from the hybrid P8 $\times$ P14, which showed a value as high as $73.6 \%$. Similarly, highly significant heterosis in the desired positive direction over mid parent was determined in four hybrids: P3 × P13 (62.7\%), 
Table 3. Mean performance of the parents and their crosses with respect to head traits in cabbage.

\begin{tabular}{|c|c|c|c|c|}
\hline S. No. & Genotypes & Head weight $(\mathrm{kg})$ & Head diameter $(\mathrm{cm})$ & Head length $(\mathrm{cm})$ \\
\hline \multicolumn{5}{|l|}{ Parents } \\
\hline 1 & P1 & 1.90 & 19.0 & 15.5 \\
\hline 2 & $\mathrm{P} 2$ & 2.70 & 22.8 & 17.8 \\
\hline 3 & P3 & 2.10 & 21.5 & 17.2 \\
\hline 4 & P4 & 3.70 & 24.5 & 20.0 \\
\hline 5 & P5 & 1.80 & 18.8 & 15.5 \\
\hline 6 & P6 & 1.00 & 19.0 & 17.0 \\
\hline 7 & P7 & 3.10 & 26.5 & 18.7 \\
\hline 8 & P8 & 2.30 & 22.2 & 17.0 \\
\hline 9 & P9 & 3.60 & 26.0 & 19.5 \\
\hline 10 & P10 & 3.10 & 25.0 & 20.0 \\
\hline 11 & P11 & 3.50 & 26.7 & 18.0 \\
\hline 12 & P12 & 2.70 & 25.5 & 18.2 \\
\hline 13 & P13 & 3.00 & 23.5 & 19.7 \\
\hline \multirow[t]{3}{*}{14} & P14 & 2.00 & 22.0 & 16.0 \\
\hline & Mean of lines & 2.63 & 23.1 & 17.9 \\
\hline & Mean of testers & 2.50 & 22.8 & 17.8 \\
\hline \multicolumn{5}{|c|}{ Crosses $(q \times \overbrace{}^{\lambda})$} \\
\hline 1 & $\mathrm{P} 1 \times \mathrm{P} 13$ & 2.32 & 24.3 & 16.2 \\
\hline 2 & $\mathrm{P} 1 \times \mathrm{P} 14$ & 2.07 & 23.2 & 18.0 \\
\hline 3 & $\mathrm{P} 2 \times \mathrm{P} 13$ & 3.73 & 24.2 & 21.3 \\
\hline 4 & $\mathrm{P} 2 \times \mathrm{P} 14$ & 3.40 & 23.5 & 19.0 \\
\hline 5 & $\mathrm{P} 3 \times \mathrm{P} 13$ & 4.15 & 29.0 & 20.8 \\
\hline 6 & $\mathrm{P} 3 \times \mathrm{P} 14$ & 3.00 & 26.0 & 19.0 \\
\hline 7 & $\mathrm{P} 4 \times \mathrm{P} 13$ & 2.45 & 23.3 & 16.5 \\
\hline 8 & $\mathrm{P} 4 \times \mathrm{P} 14$ & 2.58 & 23.8 & 19.0 \\
\hline 9 & $\mathrm{P} 5 \times \mathrm{P} 13$ & 3.20 & 26.3 & 22.0 \\
\hline 10 & $\mathrm{P} 5 \times \mathrm{P} 14$ & 2.22 & 22.4 & 16.8 \\
\hline 11 & $\mathrm{P} 6 \times \mathrm{P} 13$ & 2.12 & 22.2 & 17.0 \\
\hline 12 & $\mathrm{P} 6 \times \mathrm{P} 14$ & 2.03 & 22.3 & 13.5 \\
\hline 13 & $\mathrm{P} 7 \times \mathrm{P} 13$ & 3.17 & 26.8 & 22.2 \\
\hline 14 & $\mathrm{P} 7 \times \mathrm{P} 14$ & 2.70 & 25.8 & 18.0 \\
\hline 15 & $\mathrm{P} 8 \times \mathrm{P} 13$ & 3.48 & 30.3 & 21.3 \\
\hline 16 & $\mathrm{P} 8 \times \mathrm{P} 14$ & 3.73 & 30.8 & 20.7 \\
\hline 17 & $\mathrm{P} 9 \times \mathrm{P} 13$ & 2.47 & 23.8 & 21.0 \\
\hline 18 & $\mathrm{P} 9 \times \mathrm{P} 14$ & 2.27 & 22.3 & 16.8 \\
\hline 19 & $\mathrm{P} 10 \times \mathrm{P} 13$ & 2.00 & 20.0 & 16.0 \\
\hline 20 & $\mathrm{P} 10 \times \mathrm{P} 14$ & 2.65 & 24.3 & 18.7 \\
\hline 21 & $\mathrm{P} 11 \times \mathrm{P} 13$ & 2.48 & 22.0 & 23.2 \\
\hline 22 & $\mathrm{P} 11 \times \mathrm{P} 14$ & 2.13 & 17.3 & 19.1 \\
\hline 23 & $\mathrm{P} 12 \times \mathrm{P} 13$ & 3.06 & 26.2 & 23.0 \\
\hline \multirow[t]{4}{*}{24} & $\mathrm{P} 12 \times \mathrm{P} 14$ & 2.42 & 24.8 & 19.0 \\
\hline & Mean of hybrids & 2.74 & 24.4 & 19.1 \\
\hline & $\operatorname{LSD}(0.01)$ & 0.21 & 2.05 & 1.93 \\
\hline & CV (\%) & 25.2 & 12.8 & 12.7 \\
\hline
\end{tabular}

$\mathrm{P} 3 \times \mathrm{P} 14$ (46.3\%), P2 × P14 (44.7\%) and P6 × P14 (35.1\%). The cross P10 $\times$ P13 (-34.4\%) displayed the lowest significant heterosis over mid parent followed by the crosses P4 $\times$ P13 (-26.9\%) and $\mathrm{P} 9 \times \mathrm{P} 13$ (-25.3\%). The extent of heterosis exhibited by the hybrids over better parent for head weight varied from $-39.0(\mathrm{P} 11 \times \mathrm{P} 14)$ to $62.3 \%$
$(\mathrm{P} 8 \times \mathrm{P} 14)$. Significantly better parent heterosis was observed in all except four crosses for the trait. Out of twenty-four crosses, twelve crosses had greater head weight than the better parent; however, only eight of them showed desirable and highly significant positive heterobeltiosis. In terms of head weight, the hybrids P1 $\times$ P14, P6 $\times$ 
$\mathrm{P} 14, \mathrm{P} 7 \times \mathrm{P} 13$ and $\mathrm{P} 12 \times \mathrm{P} 13$ had non-significant positive heterosis over better parent. Percentages of negative heterosis in twelve crosses over better parent were found to be highly significant. The maximum positive and highly significant heterobeltiosis for this trait was recorded in the cross P8 $\times$ P14 (62.3\%) followed by P3 × P14 (42.9\%) and $\mathrm{P} 3 \times \mathrm{P} 13(38.3 \%)$. The minimum significantly negative level of better parent heterosis for head weight was determined in $\mathrm{P} 11 \times \mathrm{P} 14$ hybrid with $-39.0 \%$. In relation to head weight, the crosses $\mathrm{P} 8$ $\times \mathrm{P} 14, \mathrm{P} 3 \times \mathrm{P} 13, \mathrm{P} 3 \times \mathrm{P} 14, \mathrm{P} 2 \times \mathrm{P} 14$ and P6 $\times$ P14 for mid parent heterosis were the top five crosses, while the crosses $\mathrm{P} 8 \times \mathrm{P} 14, \mathrm{P} 3 \times \mathrm{P} 14, \mathrm{P} 3 \times \mathrm{P} 13$, $\mathrm{P} 2 \times \mathrm{P} 14$ and $\mathrm{P} 2 \times \mathrm{P} 13$ were the best crosses for better parent heterosis (Tables 4 and 5). According to Swaminathan et al. (1972) heterobeltiosis of more than $20 \%$ could offset the cost of hybrid seed. Thus, the crosses showing more than $20 \%$ of heterobeltiosis (viz., P8 $\times$ P14, P3 × P14, P3 × $\mathrm{P} 13, \mathrm{P} 2 \times \mathrm{P} 14$ and $\mathrm{P} 2 \times \mathrm{P} 13)$ may be exploited for hybrid cabbage production. In this study, the mean mid parent heterosis value of all combinations for head weight was positive with a value of $10.2 \%$, indicating that the hybrids had a greater head weight than their respective parents. On the other hand, the average heterosis for all crosses over better parent for the trait was in the undesirable negative direction, with a value of $-3.8 \%$ (Table 4). Heterosis breeding was recommended to improve the net head weight of cabbage by Singh (2007). In contrast to the present study, Pandey et al. (2004), Pathak et al. (2007) and Singh et al. (2009a) observed higher percentages of heterosis for net head weight in cabbage.

Head diameter is also considered as one of the important yield components in cabbage, and positive heterosis for this trait is preferable. All twenty-four crosses exhibited highly significant $(\mathrm{P} \leq 0.01)$ mid parent and better parent heterosis for head diameter in both directions. The magnitude

Table 4. Heterosis (\%) over mid parent (MP) and better parent (BP) for head traits of cabbage hybrids.

\begin{tabular}{|c|c|c|c|c|c|c|c|}
\hline \multirow[b]{2}{*}{ S. No. } & \multirow[b]{2}{*}{ Crosses } & \multicolumn{2}{|c|}{ Head weight (kg) } & \multicolumn{2}{|c|}{ Head diameter $(\mathrm{cm})$} & \multicolumn{2}{|c|}{ Head length $(\mathrm{cm})$} \\
\hline & & MP & $\mathrm{BP}$ & MP & $\mathrm{BP}$ & MP & $\mathrm{BP}$ \\
\hline 1 & $\mathrm{P} 1 \times \mathrm{P} 13$ & $-5.4 *$ & $-22.8 * *$ & $14.5^{* *}$ & $3.5 * *$ & $-8.1 * *$ & $-17.8 * *$ \\
\hline 2 & $\mathrm{P} 1 \times \mathrm{P} 14$ & 6.0 & 3.3 & $13.0^{* *}$ & $5.3^{* *}$ & $14.3 * *$ & $12.5^{* *}$ \\
\hline 3 & $\mathrm{P} 2 \times \mathrm{P} 13$ & $31.0 * *$ & $24.4 * *$ & $4.3 * *$ & $2.8^{* *}$ & $13.8 * *$ & $8.5^{* *}$ \\
\hline 4 & $\mathrm{P} 2 \times \mathrm{P} 14$ & $44.7 * *$ & $25.9 * *$ & $4.8 * *$ & $2.9^{* *}$ & $12.3 * *$ & $6.5^{* *}$ \\
\hline 5 & $\mathrm{P} 3 \times \mathrm{P} 13$ & $62.7 * *$ & $38.3 * *$ & $28.9^{* *}$ & $23.4 * *$ & $12.7 * *$ & $5.6^{* *}$ \\
\hline 6 & $\mathrm{P} 3 \times \mathrm{P} 14$ & $46.3 * *$ & $42.9 * *$ & $19.5^{* *}$ & $18.2 * *$ & $14.5 * *$ & $10.5 * *$ \\
\hline 7 & $\mathrm{P} 4 \times \mathrm{P} 13$ & $-26.9 * *$ & $-33.8 * *$ & $-2.8 * *$ & $-4.8 * *$ & $-16.8 * *$ & $-17.5 * *$ \\
\hline 8 & $\mathrm{P} 4 \times \mathrm{P} 14$ & $-9.4 * *$ & $-30.2 * *$ & $2.5 * *$ & $-2.7 * *$ & $5.6^{* *}$ & $-5.0 * *$ \\
\hline 9 & P5 × P13 & $33.3 * *$ & $6.7 * *$ & $24.5^{* *}$ & $12.1 * *$ & $25.1 * *$ & $11.9 * *$ \\
\hline 10 & $\mathrm{P} 5 \times \mathrm{P} 14$ & $16.7^{* *}$ & $10.8 * *$ & $9.6 * *$ & $1.7 * *$ & $6.9 * *$ & $5.2 * *$ \\
\hline 11 & $\mathrm{P} 6 \times \mathrm{P} 13$ & 5.8 & $-29.4 * *$ & $4.3 * *$ & $-5.7 * *$ & $-7.3 * *$ & $-13.6 * *$ \\
\hline 12 & $\mathrm{P} 6 \times \mathrm{P} 14$ & $35.1 * *$ & 1.3 & $8.6 * *$ & $1.2 * *$ & $-18.2 * *$ & $-20.6 * *$ \\
\hline 13 & $\mathrm{P} 7 \times \mathrm{P} 13$ & 3.8 & 2.2 & $7.2 * *$ & $1.1^{* *}$ & $15.7 * *$ & $12.7 * *$ \\
\hline 14 & $\mathrm{P} 7 \times \mathrm{P} 14$ & $5.9^{*}$ & $-12.9 * *$ & $6.5 * *$ & $-2.5 * *$ & $3.8 * *$ & $-3.6 * *$ \\
\hline 15 & $\mathrm{P} 8 \times \mathrm{P} 13$ & $31.4 * *$ & $16.1 * *$ & $32.8 * *$ & $29.1 * *$ & $16.4 * *$ & $8.5^{* *}$ \\
\hline 16 & $\mathrm{P} 8 \times \mathrm{P} 14$ & $73.6^{* *}$ & $62.3 * *$ & $39.6^{* *}$ & $39.1 * *$ & $25.3 * *$ & $21.6 * *$ \\
\hline 17 & $\mathrm{P} 9 \times \mathrm{P} 13$ & $-25.3 * *$ & $-31.5 * *$ & $-3.7 * *$ & $-8.3 * *$ & $7.2 * *$ & $6.8 * *$ \\
\hline 18 & $\mathrm{P} 9 \times \mathrm{P} 14$ & $-19.0 * *$ & $-37.0 * *$ & $-6.9 * *$ & $-14.1 * *$ & $-5.2 * *$ & $-13.7 * *$ \\
\hline 19 & $\mathrm{P} 10 \times \mathrm{P} 13$ & $-34.4 * *$ & $-35.5 * *$ & $-17.5 * *$ & $-20.0 * *$ & $-19.3 * *$ & $-20.0 * *$ \\
\hline 20 & $\mathrm{P} 10 \times \mathrm{P} 14$ & 3.9 & $-14.5 * *$ & $3.3 * *$ & $-2.9 * *$ & $3.7 * *$ & $-6.7 * *$ \\
\hline 21 & $\mathrm{P} 11 \times \mathrm{P} 13$ & $-23.6 * *$ & $-29.0 * *$ & $-12.3 * *$ & $-17.5 * *$ & $23.0 * *$ & $17.8 * *$ \\
\hline 22 & $\mathrm{P} 11 \times \mathrm{P} 14$ & $-22.4 * *$ & $-39.0 * *$ & $-28.8 * *$ & $-35.0 * *$ & $12.2 * *$ & $5.9 * *$ \\
\hline 23 & $\mathrm{P} 12 \times \mathrm{P} 13$ & $7.3^{* *}$ & 1.9 & $6.9 * *$ & $2.7 * *$ & $21.6 * *$ & $16.9 * *$ \\
\hline 24 & $\mathrm{P} 12 \times \mathrm{P} 14$ & 2.8 & $-10.5 * *$ & $4.6 * *$ & $-2.6^{* *}$ & $11.4^{* *}$ & $4.8 * *$ \\
\hline Mean & & 10.2 & -3.8 & 6.8 & 1.1 & 7.1 & 1.6 \\
\hline
\end{tabular}

$* \mathrm{P} \leq 0.05,{ }^{*} \mathrm{P} \leq 0.01$. 
of heterosis for the trait changed from -28.8 to $39.6 \%$ over mid parent. Out of twenty-four cross combinations, eighteen showed highly significant and positive heterosis over mid parent for head diameter. The remaining six combinations exhibited significantly negative mid parent heterosis. Among all crosses, the cross $\mathrm{P} 8 \times \mathrm{P} 14$ had the highest significant mid parent heterosis value $(39.6 \%)$, followed by crosses P8 $\times$ P13 (32.8\%), P3 $\times$ P13 (28.9\%) and P5 $\times$ P13 (24.5\%). Conversely, the lowest mid parent heterosis value $(-28.8 \%)$ was observed in the hybrid P11 $\times \mathrm{P} 14$. The better parent heterosis ranged from -35.0 to $39.1 \%$ for this trait. A total of thirteen hybrids showed significantly better parent heterosis in the desirable positive direction, while eleven hybrids had significantly negative better parent heterosis in head diameter. The heterosis over better parent for this trait was the maximum in the hybrid P $8 \times \mathrm{P} 14$ with a value of $39.1 \%$. On the contrary, minimum significant negative heterobeltiosis was exhibited by the hybrid P11 $\times$ P14 (-35.0\%). Three hybrids, P8 $\times$ P14, $\mathrm{P} 8 \times \mathrm{P} 13$ and $\mathrm{P} 3 \times \mathrm{P} 13$, demonstrated more than $20 \%$ significant desired positive heterobeltiosis. Regarding mid parent heterosis, the crosses $\mathrm{P} 8$ $\times \mathrm{P} 14, \mathrm{P} 8 \times \mathrm{P} 13, \mathrm{P} 3 \times \mathrm{P} 13$ and $\mathrm{P} 5 \times \mathrm{P} 13$ were the best crosses for head diameter. The crosses $\mathrm{P} 8 \times$ $\mathrm{P} 14, \mathrm{P} 8 \times \mathrm{P} 13$ and $\mathrm{P} 3 \times \mathrm{P} 13$ with highly significant positive heterobeltiosis effects were found to be as superior cross combinations for this trait (Tables 4 and 5). The mean mid parent heterosis value of all $\mathrm{F}_{1}$ hybrids was $6.8 \%$, which indicates that hybrids are superior to parents with respect to head diameter. The mean heterobeltiosis value for the trait was in the desirable positive direction (1.1\%), but it was relatively low (Table 4). In relation to better parent heterosis values for this trait in cabbage almost similar results were also reported by Singh et al. (2009a).

The positive direction of heterosis for head length, which is one of the main yield components in cabbage, is also considered to be desirable. The values of mid parent and better parent heterosis were highly significant $(\mathrm{P} \leq 0.01)$ in all of the crosses for the trait under consideration. Heterosis over mid parent ranged from -19.3 to $25.3 \%$. A total of eighteen cross combinations showed significant mid parent heterosis in the desired positive direction. Significant negative mid parent heterosis values for this trait were obtained from only six of the twenty-four cross combinations. Among the twenty-four hybrids studied, the highest significant positive heterosis over mid parent was achieved by the hybrid P8 $\times$ P14 (25.3\%) followed by the hybrids P5 × P13 (25.1\%), P11 × P13 (23.0\%) and P12 $\times$ P13 (21.6\%). Contrary to this, the lowest heterosis over mid parent was provided by the hybrid P10 × P13 (-19.3\%) followed by P6 × P14 $(-18.2 \%)$. Regarding head length, the magnitude of heterobeltiosis was found in the range of -20.6 to $21.6 \%$. Out of twenty-four crosses tested, fifteen crosses displayed significantly positive heterobeltiosis. With respect to head length, significant heterobeltiosis in the negative direction was noted in nine combinations. The highest significant percentage of heterobeltiosis for the trait was also noted in the hybrid P8 $\times$ P14 (21.6\%), whereas the hybrid P6 $\times$ P14 $(-20.6 \%)$ had the lowest significant better parent heterosis. Only one hybrid, P8 $\times$ P14, showed more than $20 \%$ heterobeltiosis. The hybrids P8 $\times$ P14, P5 $\times$ P13, $\mathrm{P} 11 \times \mathrm{P} 13$ and P12 $\times$ P13, which exhibited high mid parent heterosis for this trait, were promising hybrid combinations. Likewise, the crosses $\mathrm{P} 8 \times$ $\mathrm{P} 14, \mathrm{P} 11 \times \mathrm{P} 13$ and P12 $\times$ P13, which showed high significant positive heterobeltiosis, were good combinations for improving this trait (Tables 4 and 5). The average mid parent heterosis for the trait was positive, with a value of $7.1 \%$. Similarly, the mean better parent heterosis over all crosses was in the desirable positive direction with value of $1.6 \%$, which means that hybrids have a greater head length than their respective better parents (Table 4). These findings are supported by the results of Singh et al. (2009a), who also found similar better parent heterosis values for this trait in cabbage.

The results of the heterosis studies showed that some of the hybrids manifested positive heterosis while others exhibited negative heterosis, mainly 
Table 5. Number of crosses showing significant heterosis, ranges of heterosis and best crosses for head traits in cabbage.

\begin{tabular}{|c|c|c|c|c|c|c|}
\hline \multirow[b]{2}{*}{ Heterosis } & \multirow[b]{2}{*}{ Traits } & \multicolumn{2}{|c|}{$\begin{array}{c}\text { Number of crosses showing } \\
\text { significant heterosis }\end{array}$} & \multirow{2}{*}{$\begin{array}{l}\text { Range of } \\
\text { heterosis }\end{array}$} & \multirow{2}{*}{$\begin{array}{l}\text { The best } \\
\text { crosses }\end{array}$} & \multirow[b]{2}{*}{ Heterosis $(\%)$} \\
\hline & & Positive & Negative & & & \\
\hline \multirow{13}{*}{$\begin{array}{l}\text { Mid parent } \\
\text { heterosis }\end{array}$} & Head weight & 11 & 8 & -34.4 to 73.6 & $\mathrm{P} 8 \times \mathrm{P} 14$ & $73.6 * *$ \\
\hline & & & & & $\mathrm{P} 3 \times \mathrm{P} 13$ & $62.7 * *$ \\
\hline & & & & & $\mathrm{P} 3 \times \mathrm{P} 14$ & $46.3 * *$ \\
\hline & & & & & $\mathrm{P} 2 \times \mathrm{P} 14$ & $44.7 * *$ \\
\hline & & & & & $\mathrm{P} 6 \times \mathrm{P} 14$ & $35.1 * *$ \\
\hline & Head diameter & 18 & 6 & -28.8 to 39.6 & $\mathrm{P} 8 \times \mathrm{P} 14$ & $39.6 * *$ \\
\hline & & & & & $\mathrm{P} 8 \times \mathrm{P} 13$ & $32.8 * *$ \\
\hline & & & & & $\mathrm{P} 3 \times \mathrm{P} 13$ & $28.9 * *$ \\
\hline & & & & & $\mathrm{P} 5 \times \mathrm{P} 13$ & $24.5^{* *}$ \\
\hline & Head length & 18 & 6 & -19.3 to 25.3 & $\mathrm{P} 8 \times \mathrm{P} 14$ & $25.3 * *$ \\
\hline & & & & & $\mathrm{P} 5 \times \mathrm{P} 13$ & $25.1 * *$ \\
\hline & & & & & $\mathrm{P} 11 \times \mathrm{P} 13$ & $23.0 * *$ \\
\hline & & & & & $\mathrm{P} 12 \times \mathrm{P} 13$ & $21.6^{* *}$ \\
\hline \multirow{11}{*}{$\begin{array}{l}\text { Better parent } \\
\text { heterosis }\end{array}$} & Head weight & 8 & 12 & -39.0 to 62.3 & $\mathrm{P} 8 \times \mathrm{P} 14$ & $62.3 * *$ \\
\hline & & & & & $\mathrm{P} 3 \times \mathrm{P} 14$ & $42.9^{* *}$ \\
\hline & & & & & $\mathrm{P} 3 \times \mathrm{P} 13$ & $38.3 * *$ \\
\hline & & & & & $\mathrm{P} 2 \times \mathrm{P} 14$ & $25.9 * *$ \\
\hline & & & & & $\mathrm{P} 2 \times \mathrm{P} 13$ & $24.4 * *$ \\
\hline & Head diameter & 13 & 11 & -35.0 to 39.1 & $\mathrm{P} 8 \times \mathrm{P} 14$ & $39.1 * *$ \\
\hline & & & & & $\mathrm{P} 8 \times \mathrm{P} 13$ & $29.1 * *$ \\
\hline & & & & & $\mathrm{P} 3 \times \mathrm{P} 13$ & $23.4 * *$ \\
\hline & Head length & 15 & 9 & -20.6 to 21.6 & $\mathrm{P} 8 \times \mathrm{P} 14$ & $21.6^{* *}$ \\
\hline & & & & & $\mathrm{P} 11 \times \mathrm{P} 13$ & $17.8^{* *}$ \\
\hline & & & & & $\mathrm{P} 12 \times \mathrm{P} 13$ & $16.9 * *$ \\
\hline
\end{tabular}

$* * \mathrm{P} \leq 0.01$.

due to varying extent of genetic diversity between parents of different cross combinations for the head traits studied. The exploitation of hybrid vigor was judged by the per se performance of hybrids and magnitude of heterosis (Richharia and Singh, 1983). A good hybrid should manifest a high level of heterosis for commercial exploitation (Malini et al., 2006). Four hybrids, $\mathrm{P} 8 \times \mathrm{P} 14, \mathrm{P} 3 \times \mathrm{P} 13$, $\mathrm{P} 3 \times \mathrm{P} 14$ and P8 $\times$ P13, were found to be optimal, as they exhibited a higher magnitude of heterosis and also possessed high per se performance for head traits. Thus, these hybrids have the potential to improve the head traits in cabbage through heterosis breeding. In addition, a total of eleven hybrids $(\mathrm{P} 1 \times \mathrm{P} 14, \mathrm{P} 2 \times \mathrm{P} 13, \mathrm{P} 2 \times \mathrm{P} 14, \mathrm{P} 3 \times \mathrm{P} 13$, $\mathrm{P} 3 \times \mathrm{P} 14, \mathrm{P} 5 \times \mathrm{P} 13, \mathrm{P} 5 \times \mathrm{P} 14, \mathrm{P} 7 \times \mathrm{P} 13, \mathrm{P} 8 \times \mathrm{P} 13$, $\mathrm{P} 8 \times \mathrm{P} 14$ and $\mathrm{P} 12 \times \mathrm{P} 13$ ) showed positive heterosis both over mid parent and better parent for all the traits studied. The high heterosis response observed in most of the hybrids may most likely be due to the dominant nature of genes responsible for the traits studied. On the other hand, the crosses P4 $\times$ P13, P9 $\times$ P14 and P10 $\times$ P13 presented significantly negative heterosis over both mid parent and better parent for all the head traits. Such crosses are worthless for hybrid vigor in yield improvement. The negative heterosis observed in some of the crosses for different traits may be due to the combination of the unfavorable genes of the parents. Singh et al. (2009b) determined negative heterobeltiosis for all mineral elements in cabbage. Hladni et al. (2007) also reported that heterosis does not appear in all hybrid combinations of the $F_{1}$ generation and heterotic effects are different for different traits. Based on the overall hybrid effects of parental combinations, the two female parents P8 and P3 showed good performance in cross combinations for head traits. As the male parent of $F_{1}$ hybrids, the performance of the inbred line P14 was better compared to that of P13. These cabbage genotypes can be utilized as promising parents in future breeding programs to improve hybrid varieties, as they exhibited desirable hybrid effects for head traits. 
In the present study, highly significant positive heterosis regarding head traits was observed by a majority of the hybrids, indicating that this trait can be improved through heterosis breeding. The data on heterosis indicated that the best hybrid was P8 $\times$ P14, as it exhibited the maximum positive and highly significant heterosis over both mid parent and better parent for head weight, head diameter and head length. Likewise, the hybrids $\mathrm{P} 3 \times \mathrm{P} 13, \mathrm{P} 3 \times \mathrm{P} 14$ and $\mathrm{P} 8 \times \mathrm{P} 13$ showed desirable and significant heterosis both over mid parent and better parent for all the traits studied. These hybrids also showed a good per se performance for head traits. Taken together, our data indicate that the hybrids P8 $\times$ P14, P3 $\times$ P13, P3 $\times$ P14 and P8 $\times$ P13 were highly suitable for heterosis breeding based on per se performance and the magnitude of heterosis. Hence, these hybrids could be utilized for commercial exploitation of heterosis to develop high-yielding hybrid varieties of cabbage.

\section{Acknowledgements}

This research was supported by General Directorate of Agricultural Research and Policies of Turkey. The authors would like to thank Dr. Guillermo Castañón for his assistance with statistical analysis.

\section{Resumen}

B. Kibar, O. Karaağaç y H. Kar. 2015. Heterosis de las características productivas de la cabeza del repollo (Brassica oleracea var. capitata). Cien. Inv. Agr. 42(2):205-216. Esta investigación se ha realizado para investigar la dirección y la dimensión de heterosis en los veinticuatro mestizajes correspondiendo con las características cabezales productivas del repollo (Brassica oleracea var capitata L.). El experimento de area se hizo durante la temporada 2011-2012, en el Instituto de Investigaciones Agriculturas en Samsun, Turkía. Los mestizajes y los portainjertos se evaluaron en el diseño en bloques aleatorizados, con tres repeticiones. Para hacer la estimación de heterosis de portainjerto superior y media de cada mestizaje se midió el peso, el diámento y la longitud de la cabeza de repollo. Para todas las caracteristicas de la cabeza, la dirección y la dimención del heterosis medio y superior entre los mestizajes fue muy variable. En los mestizajes de P8 $\times$ P14, el peso de la cabeza $(73,6$ y $62,3 \%$, respectivamente), el diámetro ( 39,6 y 39,1 , respectivamente), y la longitud de la cabeza ( 25,3 y $21,6 \%$, respectivamente), se observó un maáimo y una cantidad importante de heterosis en el portainjerto medio y superior suficiente. En este estudio, las combinaciones de mestizajes P8 $\times \mathrm{P} 14, \mathrm{P} 3 \times \mathrm{P} 13, \mathrm{P} 3 \times \mathrm{P} 14$ y $\mathrm{P} 8 \times \mathrm{P} 13$, resultaron ser prometedoras en cuanto al rendimiento per se de las caracteristicas de la cabeza y la magnitud de la heterosis. Estos mestizajes se pueden elegir para aprovechar de vigor híbrido de heterosis, en el comercio. Por lo cual, las informaciones obtenidas gracias a estos estudios, pueden ser beneficiosos y vitales para cultivar unos tipos de mestizajes que tienen una productividad superior y mejores características de la cabeza del repollo a través del mejoramiento de heterosis por los agricultores.

Palabras clave: Características de la cabeza, col, componentes de rendimiento, mejoramiento, repollo, productividad, vigor híbrido.

\section{References}

Antonova, G. 2009. Study on variation, heritability and correlation in open pollinated cultivars and new breeding lines of late head cabbage. Acta Horticulturae 830: 143-150.

Chiang, M.S., C. Chong, B.S. Landry, and R. Crete. 1993. Cabbage. p. 100-152. In: Kalloo, G., and 
B.O. Berg (eds.). Genetic Improvement of Vegetable Crops. Pergamon Press, New York, USA.

Fonseca, A., and F.L. Patterson. 1968. Hybrid vigour in a seven parent diallel cross in common winter wheat (T. aestivum L.). Crop Science 8: 85-88.

Hladni, N., D. Škorić, M. Kraljević-Balalić, Z. Sakač, and V. Miklič. 2007. Heterosis for agronomically important traits in sunflower (Helianthus annuus L.). Helia 30(47): 191-198.

Hounsome, N., B. Hounsomei, D. Tomos, and G.E. Jones. 2009. Changes in antioxidant compounds in white cabbage during winter storage. Postharvest Biology and Technology 52: 173-179.

Kar, H., O. Karaagac, B. Kibar, and A. Apaydın. 2008. Identification of morphological traits of domestic $F_{1}$ hybrid cultivar candidates developed in white head cabbage VII. Vegetable Growing Symposium, 26-29 August, Yalova. p. 40-45.

Kopsell, D.E., D.A. Kopsell, M.G. Lefsrud, and C.J. Curran. 2004. Variability in elemental accumulations among leafy Brassica oleracea cultivars and selections. Journal of Plant Nutrition 27: 1813-1826.

Malini, N., T. Sundaram, S.H. Ramakrishnan, and S. Saravanan. 2006. Prediction of hybrid vigour for yield attributes among synthesized hybrids in rice (Oryza sativa L.). Research Journal of Agricultural and Biological Sciences 2: 166-170.

Melaku, A. 1993. Heterosis and combining ability for yield and other quantitative characters in haricot bean (Phaseolus vulgaris L.). MSc Thesis. Presented to the School of Graduate Studies of Alemaya University. 103 pp.

Pandey, V.D., H.K. Pandey, Z. Ahmed, and N. Kumar. 2004. Heterosis for net head weight and vit ' $\mathrm{C}$ ' in cabbage (Brassica oleracea var. capitata). Vegetable Science 31: 177-178.

Pathak, S., J. Kumar, V. Sagar, and S. Verma. 2007. Heterosis and combining ability for marketable yield and component traits in cabbage (Brassica oleracea var capitata). Indian Journal of Agricultural Sciences 77: 97-100.

Posta, G., and V. Berar. 2006. Researches concerning the yield performances of the early cabbage hybrids cultivated in the field conditions. Buletinul
Universitatea de Ştiințe Agricole şi Medicină Veterinară, Cluj-Napoca. Seria Horticultura 63: 101-105.

Prakash, C., and T.S. Verma. 2004. Heterosis in cytoplasmic male sterile lines of cabbage. Cruciferae Newsletter 25: 49-50.

Richharia, A.K., and R.S. Singh. 1983. Heterosis in relation to per se performance and effects of general combining ability in rice. Progresses scientific meeting on genetics and improvement of heterotic systems, Tamil Nadu Agric. Univ., Coimbatore. India.

Shull, G.H. 1952. Beginnings of The Heterosis Concept. p. 14-48. In: Gowen, J.W. (ed.). Heterosis. State College Press, Ames, Iowa, USA.

Singh, B.K. 2007. Studies on variability and heterosis of important economic and nutritive traits in cabbage. Ph.D. Thesis. Indian Agricultural Research Institute, New Delhi, India. 108 pp.

Singh, H., S.N. Sharma, and R.S. Sain. 2004. Heterosis studies for yield and its components in bread wheat over environments. Hereditas 141: 106-114.

Singh, B.K., S.R. Sharma, and B. Singh. 2009a. Heterosis for antioxidants and horticultural traits in single cross hybrids of cabbage (Brassica oleracea var. capitata). Indian Journal of Agricultural Sciences 79: 703-708.

Singh, B.K., S.R. Sharma, and B. Singh. 2009b. Heterosis for mineral elements in single crosshybrids of cabbage (Brassica oleracea L. var. capitata). Scientia Horticulturae 122: 32-36.

Singh, B.K., S.R. Sharma, and B. Singh. 2009c. Combining ability for superoxide dismutase, peroxidase and catalase enzymes in cabbage head (Brassica oleracea var. capitata L.). Scientia Horticulturae 122: 195-199.

Singh, B.K., S.R. Sharma, and B. Singh. 2010a. Heterosis for superoxide dismutase, peroxidase and catalase enzymes in the head of single crosshybrids of cabbage (Brassica oleracea var. capitata). Journal of Genetics 89: 217-221.

Singh, B.K., S.R. Sharma, P. Kalia, and B. Singh. 2010b. Character association and path analysis of morphological and economic traits in cabbage (Brassica oleracea var. capitata L.). Indian Journal of Agricultural Sciences 80: 116-118. 
Singh, B.K., S.R. Sharma, and B. Singh. 2011. Combining ability for antioxidants and economic traits in cabbage. Indian Journal of Horticulture 68: 490-497.

Swaminathan, M.S., E.A. Siddique, and S.D. Sharma. 1972. Outlook for Hybrid Rice in India. In: Robert F., and J.R. Chandler (eds.). Rice Breeding. International Rice Research Institute (IRRI). Los Baños, Philipinnes. p. 609-613.

TUIK. 2014. Turkish Statistical Institute, Ankara. Available online at: http://tuikapp.tuik.gov.tr/bit- kiselapp /bitkisel.zul (Website accessed: March 19, 2014).

TUMAS. 2013. Turkey Meteorological Archive System, Climate Statistics. Ankara: Turkish State Meteorological Service Publications. Available online at: http://tumas.mgm.gov.tr/wps/portal (Website accessed: February 27, 2014).

Wynne, J.C., D.A. Emery, and P.M. Rice. 1970. Combining ability estimates in Arachis hypogea L. II. Field performance of $F_{1}$ hybrids. Crop Science 10(6): 713-715. 